\title{
Analysis of the Impact of Globalization on the Global Labor Force
}

\author{
Maria Loredana Popescu1, Ovidiu Andrei Cristian Buzoianu², Victor \\ Troaca $^{3}$ and Valentin Lazar $^{4}$ \\ ${ }^{1}$ Bucharest University of Economic Studies, Associate Professor, Bucharest, Romania \\ ${ }^{2}$ Bucharest University of Economic Studies, Associate teacher; Department of Management, \\ Bucharest, Romania \\ ${ }^{3}$ Bucharest University of Economic Studies, PhD student, Bucharest, Romania \\ ${ }^{4}$ Bucharest University of Economic Studies, Director at the Research and Innovation Management \\ Department, Bucharest, Romania
}

\begin{abstract}
.
Research background: Research background is written after the literature review. For example, german researcher Ulrich Beck claims that contemporary society has entered a new phase in which the nature of natural resources has become stressful. G. Barraclough argued that no matter how important the political, cultural, ecological factors ultimately are, it is the economy that determines the evolution of the globalization process.

Purpose of the article: The present article follows the identification of the impact on the phenomenon of the current phenomenon of the naming of globalization on the labor force and how the phenomenon of migration is conditioned with the main factors.

Methods: This article starts from the hypothesis of the influence of globalization in terms of the global labor force, as well as the migration phenomenon caused by the economic factor mainly. In the realization that it is possible to analyze specialized literary analyzes on the one hand, but if one analyzes past, present and future data (estimation), provided by the World Labor Organization. Measurement tools and procedures can be measured for all important or reasonable features. Analyze after a detailed realization, provided that appropriate techniques can be analyzed.

Findings \& Value added: Following this research, it was found the connection between globalization and the labor market, along with its impact on the migration phenomenon, highlighted by the economic factor, for better pay. The article adds value through the analysis created both globally and regionally (European level) and the interpretation of statistical data related to population migration.
\end{abstract}

Keywords: globalization; worldwide; migration; workforce

\footnotetext{
* Corresponding author: buzoianuovidiu@yahoo.com
} 
JEL Classification: F66; J21

\section{Introduction}

With an origin somewhere in the 1960s, the term globalization began to be used more and more frequently in the late 1980s, gradually becoming the concept of the 1990s. Globalization did not benefit from a clear definition from the beginning, it was approached from various angles. view being thus controversial. Globalization is the process of widening, deepening and accelerating global interconnections in all aspects of contemporary socioeconomic life. Therefore, not only in the economic field, as it has long been perceived, but also in the social, political, technological and cultural [1].

R. Robertson stated that "the development of this process becomes at some point independent of what is happening within the national society, noticing that the unity of views on major, fundamental issues is the only way to survive.

German researcher Ulrich Beck claims that contemporary society has entered a new phase in which the nature of natural resources has become stressful. The threat of depletion of many natural resources has become an undeniable reality. He recognizes that the modernization of society is the primary force of globalization [2]. He states that ecological risks globalize, because they universalize and equalize people's consciousness, causing them to be more united in everything they do, in the face of the common dangers that threaten them, all living under the same atmospheric roof.

G. Barraclough argued that no matter how important the political, cultural, ecological factors ultimately are, it is the economy that determines the evolution of the globalization process. For some, globalization is identified with "Americanization," others associate the term with increasing the importance of the world market, while a third category uses the concept to describe an ideological reality- as a victory of the market economy.

One of the most used definitions of the concept is: "Globalization is the process by which geographical distance becomes a less and less important factor in establishing and developing cross-border economic, political and socio-cultural relations $[3,4]$.

The phenomenon of globalization can be characterized by 2 dimensions:

- intensity (for its intensive side) - focuses on increasing interconnection and interdependence, interactions and transnational flows. As intensity, globalization implies integration, interconnection, interdependence, openness and admits as synonyms the terms globalism, universalization, homogeneity.

- amplitude (for its extensive side) - emphasizes the geographical coverage of the phenomenon. As localization it means disintegration, independence, closure and signifies by opposition nationalism / regionalism, spatial distension, separatism, heterogeneity.

Based on the dimensions of manifestation and representation as an intensive and extensive process, globalization can be defined as: widening, deepening and accelerating global interconnection in all aspects of contemporary social life.

The concept of globalization is interconnected with the field of international migration, referring specifically to the movement of people between regions and continents, be they migration in search of work, diaspora or a better life [5].

This process of globalization, seen from the perspective of migration, is an old phenomenon that preceded the formation of nation-states. The movement of salaried workers, reacting to market forces (of supply and demand) is an important aspect of the mass movement of human beings around the world. But, the phenomenon of migration also intersects with the political, cultural and military power, the global or regional models of migration being multiple. 


\section{Methods}

This article starts from the hypothesis of the influence of globalization in terms of the global labor force, as well as the migration phenomenon caused by the economic factor mainly. In the realization that it is possible to analyze specialized literary analyzes on the one hand, but if one analyzes past, present and future data (estimation), provided by the World Labor Organization. Measurement tools and procedures can be measured for all important or reasonable features. Analyze after a detailed realization, provided that appropriate techniques can be analyzed.

\section{Discussions}

Contemporary migration is a rapidly expanding phenomenon, the main driver of which is globalization. According to the United Nations Population Division, international migration now numbers about 200 million people, double that of 25 years ago [6].

The total movement of a population is composed of the natural movement and the migratory movement [7]. The population of a country or an administrative-territorial unit changes its number, not only as a result of inflows and outflows caused by births and deaths, but also as a result of immigration and emigration [8]. Because migratory flows can affect particular groups of people in terms of age and sex, migration changes not only the number of the population, but also its structure by sex and age and other characteristics. The movements of the inhabitants can be made outside the locality, between countries, they can have a shorter or definitive duration, which makes necessary a detailed classification of the different types of migration. Being part of the total movement of a population, migration concerns not only demography, but also sociology, which studies the phenomena of adaptation or acculturation of migrants, the influence of migration on social institutions, on the structure of the population [9].

In relation to the official borders of a country, migration can be:

- internal migration: the totality of displacements, accompanied by the definitive change of the habitual domicile within a country, between the territorial-administrative units;

- external (international) migration: the totality of displacements, accompanied by the definitive change of domicile, between two countries.

In relation to the place of destination (arrival), respectively of departure (origin), the terms immigration and emigration are used:

- immigration: migration seen from the point of view of the destination locality. The people included in this migratory flow are called immigrants.

- emigration: migration seen from the point of view of the place of departure. The people included in this migratory flow are called emigrants.

Regarding a definition of the condition of "migrant", there is no universally accepted and valid definition, but the definition given by the United Nations is very pertinent: "any person who changes his territory where he usually lives". Thus, tourists and business people do not fall into this category, because their travels do not involve changing the usual place of residence. Statistically, the migrant population can be directly determined by the number of foreigners in a country: those registered by country of birth or that percentage of the population with foreign nationality [10].

Confusion regarding migrants is exacerbated, as it is considered that the migrant's nationality must correspond to the migrant's country of birth, but the nationality can be changed, while the place of birth cannot be changed, at least from a legal perspective [11]. Thus, a person may be born in a territory, but may be qualified as a foreigner if he has foreign parents or vice versa; a person born may be considered a national citizen, but characterized 
as a foreigner if he is born abroad. It can be seen that there are a variety of national criteria for defining the status of migrant within the states of the world [12].

\subsection{Causes of migration}

Like any social phenomenon, migration is conditioned by several economic, social, demographic, geopolitical, cultural factors [13]. The main causes and factors of the manifestation of the migration phenomenon:

Wage inequalities - even if the influence of non-economic factors cannot be neglected in making the decision to migrate, the main reason why people leave (temporarily or permanently) the country of origin is the differences in income between the area of origin and destination. Wage inequalities at the international level are extremely pronounced and would justify departures from the poorest to the richest regions of the world [14]. These differences in income levels are the main cause of cross-border migration.

Unfavorable social conditions in immigrant-supplying countries seriously influence the size of the migration phenomenon, as follows: unemployment rate, poverty, growth rate, level of investment, corruption, level of trust in state institutions, existing political regime, its ability to optimally solve people's problems . In the periods of recession that a state is going through, the desire of its citizens to emigrate increases [15].

Also, in totalitarian political regimes (such as the communist one), human migration was fueled by political reasons. Conflict or warfare causes people to migrate in search of safer countries.

The need for labor, ie demand, in certain economic sectors of developed countries remains a primary cause, while the search for a job is the main goal of newcomers, is supply. Deficits occur during periods of economic growth, and they cannot always be covered by the local labor force [16]. Therefore, the appeal to immigrants appears as a necessity for maintaining the pace of economic growth, profit and productivity in an extremely competitive world.

The policies pursued by the developed states in the direction of attracting immigrants represent an important factor, favorable to migration. These policies are economically justified and are aimed at covering labor market deficits. These policies are aimed in particular at attracting highly skilled immigrants (brain drain), but also at immigrants working in sectors rejected by the citizens of the host country.

The effectiveness of these types of policies has been verified especially in the USA, Canada, Australia, countries that allow themselves a recruitment, including through universities, in order to facilitate the integration and assimilation of newcomers [17]. Medicine and new technologies remain the areas most protected by the policies adopted by developed countries in this regard. As a result, poor states lose the "gray matter" in which they have invested, thus losing in the competition for development in favor of rich countries. Thus, migration is self-sustaining.

Reducing transport and communication costs obviously favors cross-border migration. The movement of people is stimulated not only by the reduction of transport and communication costs, but also by the increasing speed of information transmission, the speed of connections between different parts of the globe [18]. The immigrant's ties with his family and country of origin are becoming easier. A new culture of mobility is emerging, supported by the new media and thus the concept of "transnational community" is gaining more and more substance in reality. Connections between people are widening, borders are becoming more permeable, and travel is much faster and cheaper. Therefore, migration has favorable conditions in these processes brought by the wave of change with the information revolution. Removing artificial barriers to the movement of people encourages transnational movement. The example of the Schengen area is relevant in this case. Citizens of the states that have acceded to the Schengen agreement can now travel freely to Europe. 


\section{Results}

As a phenomenon that has marked the evolution of mankind, the migration of people worldwide will continue to influence the history of the world. Through migration, globalization materializes, it has zonal peculiarities, although it is a process in full swing.

Poverty, lack of opportunities, inequalities in one's own country are the roots from which migration develops. Trends are increasing poverty and increasing inequality [19]. The root causes of population movements around the world remain difficult to remove. However, by raising awareness of government decision-makers, the effects of migration, both positive and negative, can be predicted globally, in order to maintain a dynamic balance, which can ensure its controllability and predictability.

Therefore, migration will have favorable growth conditions in the coming years. In addition, the state 's policies to reduce the causes, which lead to migration, are still not accompanied by convincing results, and the outlook remains bleak. The severity of global disparities is reflected in a number of data that are more than relevant: "The net worth of the world's 358 billion is equal to the combined income of $45 \%$ of the world's poorest people 2.5 billion."

This difference fuels the feelings of dissatisfaction of the citizens of poor countries and supports the desire to emigrate to more prosperous regions of the globe. As these inequalities continue to exist, migration has every chance of increasing.

However, the existence of migration is not only conditioned by poverty and inequality. Immigrant host countries are facing an unprecedented demographic aging process. The need for labor in developed countries to cover labor market deficits means attracting immigrants. Intensifying global communication, the movement of goods, capital, ideas will act in favor of increasing the movement of people. The consequences of globalization are favorable to sustaining migratory flows worldwide. Rich countries will continue to be attractive to the world's poor, and the for-profit migration of people will mark many components of social life. Illegal migration will increase, despite increasing control efforts and measures from developed countries, as long as causal chains increase in intensity.

The changes produced by migration can be found at all levels of the social system. For the society of origin, progress appears at the economic and social level, but regressions are also possible at the political, demographic, cultural level, reciprocal being also valid, even in other possible combinations. In the short and medium term, there are positive effects at the economic level, but also regresses in political and cultural terms, by manifesting feelings of hostility towards immigrants and the emergence of political forces that capitalize on them. Through its effects, migration will continue to have a strong influence on development.

Geographical proximity between states is another factor that influences the size and character of migration. The geographical proximity makes its mark all the stronger, the greater the differences in development between states and the freer the movement. The geographical factor plays an especially important role in supporting seasonal migration, such as between Mexico and the USA, between Morocco and Spain, between Romania and Hungary or between the Republic of Moldova and Romania. Geographical proximity is an element that stimulates circulatory labor migration rather than permanent migration.

At European level, the distances between states with significant differences in development are becoming easier to cross, and the geographical factor is making its full contribution to strengthening communication links, especially through the movement of people [20].

Demographic aging is a structural cause that fuels global migration. Rich states are also the most affected by this phenomenon, while less developed countries have a large number of young people. As migration is associated with the young population, it is obvious that this demographic aging is being addressed by the migration of young people from poor countries. 
The increase in the share of the elderly population involves many consequences, from the need for a replacement workforce to the emergence of new jobs in the field of social assistance [21].

Demographic aging is a phenomenon that supports the phenomenon of cross-border migration to the highest degree, including the demand for new private, state or mixed services on social assistance for these people. The general feeding of the migration phenomenon takes concrete forms of manifestation, and obviously, particularities depending on the place of origin and destination.

By 2050 , it is estimated that $22 \%$ of the world's population will be 60 years of age or older. Since 1950, developed countries have had a higher percentage of the elderly than developing countries (see figure 1).

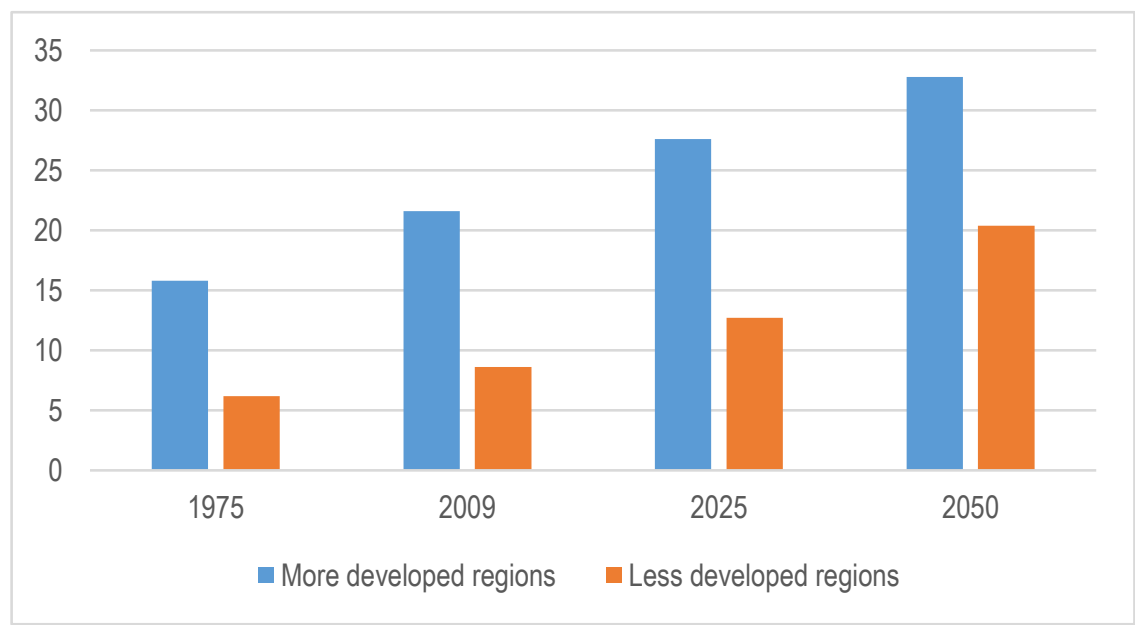

Fig. 1. Population aged 60 years, as a percentage of the total population 1975-2050; Source: International Organisation for labor

The more developed regions include all regions of Europe and North America, Australia, New Zealand and Japan. Less developed regions include all regions of Africa, Asia (excluding Japan), Latin America and the Caribbean, and regions of Malaysia, Micronesia and Polynesia. The terms "developed countries" and "developing countries" are used to designate the group of countries or areas located in the most developed regions, respectively the least developed regions of the world. In 2019, 49 countries were considered the least developed countries, of which 33 in Africa, 10 in Asia, one country in Latin America and the Caribbean and 5 in Oceania.

The elderly population is growing faster than the total population in virtually every region of the world. The difference in growth rates between the elderly population and the total population is growing. If by 2010 , there was an increase in the population aged 60 and 80 years, respectively, it is estimated that this growth will continue until 2025. From 2025, according to the graph, there is a decrease in the growth rate (see Figure 2.) 


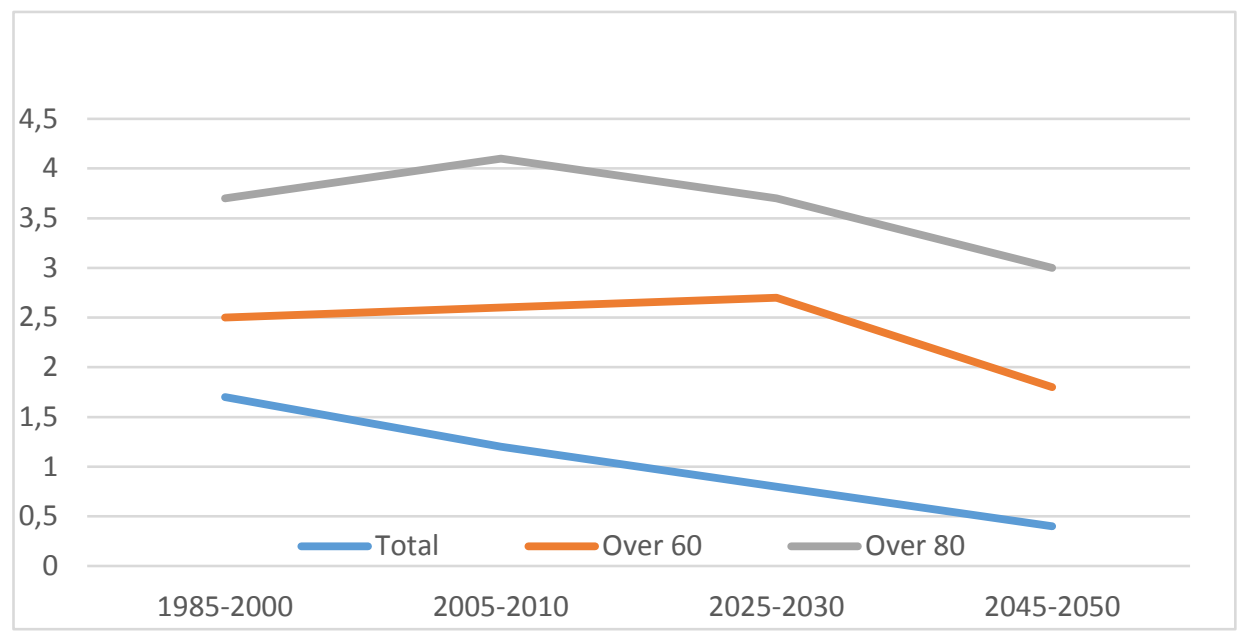

Fig. 2. Average annual growth rate, of the total population, of the population over the age of 60 and over the age of 80, 1950-2050; Source: International Organisation for labor

The society that supplies immigrants also suffers some losses, due to the migratory movement of its citizens. The skilled labor force is lost, so a social and private investment at the same time $[22,23]$. In the table 1 , we can identified the many factors of rejection and atrraction of migrations.

Table 1- Factors of rejection and attraction of migrations

\begin{tabular}{|c|c|c|c|}
\hline $\begin{array}{l}\text { Nr. } \\
\text { crt. }\end{array}$ & $\begin{array}{l}\text { Motivations } \\
\text { of migration }\end{array}$ & Rejection factors & Attraction factors \\
\hline 1. & $\begin{array}{l}\text { Economics and } \\
\text { demographics }\end{array}$ & $\begin{array}{ll}\text { - } & \text { Poverty; } \\
\text { - } & \text { Vacancy / } \\
& \text { unemployment; } \\
\text { - } & \text { Low income; } \\
\text { - } & \text { High fertility rate; } \\
\text { - } & \text { Poor health and } \\
& \text { educational } \\
& \text { assistance; } \\
\end{array}$ & $\begin{array}{l}\text { - The possibility of } \\
\text { increasing incomes; } \\
\text { - The possibility of raising } \\
\text { the standard of living; } \\
\text { - Personal/professional } \\
\text { development; }\end{array}$ \\
\hline 2. & Politics & $\begin{array}{ll}- & \text { Conflict, insecurity, } \\
& \text { violence } \\
\text { - } & \text { Poor government } \\
\text { - } & \text { Corruption } \\
\text { - } & \text { Human rights abuses } \\
\end{array}$ & $\begin{array}{ll}\text { - } & \text { Safety and security } \\
\text { - } & \text { Political freedom }\end{array}$ \\
\hline 3. & $\begin{array}{l}\text { Social and } \\
\text { cultural }\end{array}$ & $\begin{array}{l}\text { - Discrimination based } \\
\text { on ethnicity, gender, } \\
\text { religion, etc. }\end{array}$ & $\begin{array}{ll}\text { - } & \text { Family reunification } \\
- & \text { "Ethnic" migration } \\
\text { - } & \text { Elimination of } \\
& \text { discrimination }\end{array}$ \\
\hline
\end{tabular}

Source: World Bank, Migration and Remittances, 2019; 


\section{Conclusions}

Globalization is a current phenomenon of great complexity, not having a proper definition, but which includes a variety of processes targeting multiple societal areas. Economic globalization may first have an impact on the number of jobs available in the economy, and thus affect key macro-economic variables such as the unemployment rate and the employment-to-population ratio. The issue is made more complex by the fact that the impact can be different at the micro-economic level (establishment, enterprise, economic activity) and at the macro-economic level (total economy), as well as in the short / long term . Economic globalization and employment are multidimensional and dynamic. They also interact with each other. Improvement in labor market conditions will also require a reorientation of development policies at the nation to land global levels, particularly with respect to the speed and pattern of integration of developing countries into the global economy. Strengthening global economic cooperation and technological progress create opportunities and challenges, hopes and fears.

Today, in an increasingly interconnected world, international migration has become a reality that reaches almost every corner of the world, with distinctions of country of origin, transit or destination often becoming obsolete.

Modern transport has made people's mobility more accessible, cheaper and faster. At the same time, conflict, poverty, inequality and the lack of decent jobs are among the reasons forcing people to leave their homes in search of a better future for themselves and their families. When supported by appropriate policies, migration can contribute to sustainable and inclusive economic growth and economic development in home and host communities. international migration has increased in magnitude and complexity, due to growing demographic differentiation, new global and political dynamics, the technological revolution and social networks, with a profound impact on the socio-economic and ethnic composition of society.

\section{References}

1. Cotlear, D., Nagpal, S., Smith, O., Tandon, A., \& Cortez, R. (2015). Going universal: how 24 developing countries are implementing universal health coverage from the bottom up. The World Bank.

2. Shahbaz, M., Mallick, H., Mahalik, M. K., \& Hammoudeh, S. (2018). Is globalization detrimental to financial development? Further evidence from a very large emerging economy with significant orientation towards policies. Applied Economics, 50(6), 574595.

3. Bran, F., Rădulescu, C. V., Bodislav, D. A., \& Burlacu, S. (2020). Environmental risks in the context of globalization. Economic Convergence in European Union, 17, 350-356.

4. Bran, F.., Alpopi, C., \& Burlacu, S. (2018). Territorial Development-Disparities between the Developed and the least Developed Areas of Romania. LUMEN Proceedings, 6(1), 146-155.

5. Özden, Ç., \& Schiff, M. (2007). International migration, economic development and policy. Washington, DC: World Bank and Palgrave Macmillan.

6. Borjas, G. J. (2015). Immigration and globalization: A review essay. Journal of Economic Literature, 53(4), 961-74.

7. Alpopi, C., Burlacu, S., \& Ioviţu, M. (2018). Procesul de globalizare şi politicile ecologice. In Competitivitatea şi Inovarea în Economia Cunoaşterii, 2, 317-324. 
8. Jessop, B. (2016). The developmental state in an era of finance-dominated accumulation. In The Asian developmental state. Palgrave Macmillan, New York, 27-55.

9. Coe, N. M., \& Yeung, H. W. C. (2015). Global production networks: Theorizing economic development in an interconnected world. Oxford University Press.

10. Ratha, D. K., De, S., Schuettler, K., Seshan, G. K., \& Yameogo, N. D. (2018). Migration and remittances: recent developments and outlook-transit migration (No. 129443, pp. 1-51). The World Bank.

11. Teichman, J. A. (2016). The politics of inclusive development: Policy, state capacity, and coalition building. Springer.

12. Teichman, J. A. (2016). Conclusions: The Politics and Policies of Inclusive Development. In The Politics of Inclusive Development. Palgrave Macmillan, New York, 159-179.

13. Ionita, F., Burlacu, S., \& Gaidargi, A. (2009). Modern approaches of the management of alternative trade systems. Rev. Int. Comparative Manage.

14. Costache, G., Marinas, C. V., Igret, R., \& Burlacu, S. (2015). Internship in the HR department-organizational and individual perspectives. In Proceedings of the 9th International management conference: Management and innovation for competitive advantage, 359-370.

15. Jianu, I., Dobre, I., Bodislav, D. A., Radulescu, C. V., \& Burlacu, S. (2019). The implications of institutional specificities on the income inequalities drivers in european union. Economic Computation and Economic Cybernetics Studies and Research, 53(2), 59-76.

16. Chernyak O, .Chernyak Y, (2019), Modern trends of the international labor force migration. In SHS Web of Conferences, 65, 09001.

17. Goldberg P., Pavcnik N., (2007). Distributional Effects of Trade Liberalization in Developing Countries. Journal of Economic Literature, 45(1), 39-82.

18. Zaidi, S. A. H., Wei, Z., Gedikli, A., Zafar, M. W., Hou, F., \& Iftikhar, Y. (2019). The impact of globalization, natural resources abundance, and human capital on financial development: Evidence from thirty-one OECD countries. Resources Policy, 64, 101476.

19. Heintz, J. (2019). Global labor standards: Their impact and implementation. In The Handbook of Globalisation, Third Edition. Edward Elgar Publishing, 225-239.

20. Docquier, F., Kone, Z. L., Mattoo, A., \& Ozden, C. (2019). Labor market effects of demographic shifts and migration in OECD countries. European economic review, 113, 297-324.

21. Profiroiu, A., Burlacu, S., \& Sabie, O. (2019). Reform of the pension system in Romania. Calitatea, 20(S2), 521-524.

22. Madsen, J. B., Islam, M. R., \& Doucouliagos, H. (2018). Inequality, financial development and economic growth in the OECD, 1870-2011. European Economic Review, 101, 605-624.

23. Ratha, D., De, S., Plaza, S., Schuettler, K., Shaw, W., Wyss, H., \& Yi, S. (2016). Migration and development brief April 2016: migration and remittances-recent developments and outlook. The World Bank. 